\author{
Anna PRUSAK ${ }^{1}$ \\ Piotr KAFEL ${ }^{2}$ \\ Piotr STEFANÓW ${ }^{3}$ \\ Jacek STROJNY ${ }^{4}$ \\ Monica GARCIA-MELON ${ }^{5}$
}

\title{
THE APPLICATION OF THE AHP RISK-BENEFIT ASSESSMENT IN CERTIFICATION OF ORGANIC FARMING
}

\begin{abstract}
The objective of the research is to develop the risk-benefit assessment models based on the Analytic Hierarchy Process (AHP) and test them in certification of organic products. The ISO Guide 65 /EN 45011 standard and Council Regulation (EC) No 834/2007 oblige the certification bodies to conduct risk assessment during certification process. However, no specific methodology of risk assessment has been provided in this respect. The AHP decomposes a complex problem into a hierarchy involving goal, criteria, and decision variants. Two hierarchical models, risk and benefit, were constructed based on the relevant publications and consultations with the key experts from one of the nine Polish third party certification bodies (CB), with experience in certification of organic products. Both models have the same decision variants considered in the process of surveillance. The results show that parallel production of conventional products and production of the same goods in organic and conventional versions appeared to be the major risk factors in organic farming. In benefit model, increased trust to certified products and minimization of costs of improper decisions were the most important. The AHP-based models proved very useful in risk-benefit assessment of organic producers and demonstrated a new approach to risk assessment. However, several conditions must be fulfilled before their implementation in practice, such as adjustment to individual needs of a certification body and refinement of the quality management system.
\end{abstract}

Keywords: AHP, certification, risk-benefit analysis, risk assessment, organic farming, third party certification

\section{WPROWADZENIE}

In recent years, a dynamic development of the market for organic products can be observed. There are well described benefits and difficulties of organic farming. Organic farming may provide two types of economic benefits. It may reduce rural poverty by providing market access and higher profits through a combination of higher prices and

${ }^{1} \mathrm{PhD}$ Anna Prusak, Department of Quality Management, Krakow University of Economics, Kraków, Poland

${ }^{2}$ PhD Piotr Kafel, Department of Quality Management, Krakow University of Economics, Kraków, Poland.

${ }^{3}$ PhD Piotr Stefanów, Department of Statistics and Demography, A.F. Modrzewski Krakow University, Krakow, Poland.

${ }^{4}$ PhD Jacek Strojny, Department of Economics, Rzeszow University of Technology, Rzeszow, Poland, e-mail: jstrojny@prz.edu.pl (corresponding author)

${ }^{5}$ PhD Monica Garcia Melon, Department of Projects Engineering, Universitat Polictecnica de Valencia, 46020 Valencia, Spain. 
more resilient yields. In developing countries, organic farming may potentially boost the local economy in the long-term perspective ${ }^{6}$. There are researches that discuss economic effects of the organic production system ${ }^{7}$. Under the current EU law, the basic document containing the requirements for organic production is Council Regulation (EC) No $834 / 2007$ of 28 June $2007^{8}$ on organic production and labeling of organic products and repealing Regulation (EEC) No 2092/91 and the regulations implementing this Regulation. According to this regulation, member states shall set up a system of controls and designate one or more competent authorities responsible for controls in conformity with Regulation (EC) No 882/2004. This process is supervised by each EU member state, which is responsible for establishing an inspection system with the competent authorities to ensure adherence to the obligations established in the organic Regulation (EC) $834 / 2007^{9}$. Member states could choose who performs the certification: a public authority or a third party certification bodies ${ }^{10}$. The third-party certification is a conformity assessment activity that is performed by the control body (CB), that is independent of the person or organization that provides the object, and of user interests in that object ${ }^{11}$. In Poland, competent authority had delegated control tasks to third party certification bodies. This companies must meet the criteria describe in article 27.5 of the Council Regulation (EC) No 834/2007. One of the requirements imposes on the certification body the obligation to implement management system according the ISO Guide 65 or European Standard EN 45011or its new edition ISO $17065^{12}$.

Requirements of the ISO Guide 65 /EN 45011 standard and Council Regulation (EC) No $834 / 2007^{13}$ forced certification bodies to use the risk assessment process during the certification process. Moreover, in Regulation (EC) No 882/2004, as a general rule, the official food and feed controls shall be carried out regularly, on a risk basis and with appropriate frequency. According to all these requirements, certification bodies that certify organic farming products are forced to implement risk assessment approach in their work. The implementation of standards within third party certification is assured through a rig-

\footnotetext{
${ }^{6}$ Kleemann L., Abdulai A., Organic certification, agro-ecological practices and return on investment: Evidence from pineapple producers in Ghana, "Ecological Economics" 93 (2013), pp. 330-341.

${ }^{7}$ Beuchelt T.D., Zeller M., Profits and poverty: Certification's troubleed link for Nicaragua's organic and fairtrade coffee producers, "Ecological Economics" 70 (2011), pp. 1316-1324; Uematsu H., Mishra A.K., Organic farmers or conventional farmers: Where's the money?, "Ecological Economics" 78 (2012), pp. 55-62; Lobley M., Butler A., Reed M., The contribution of organic farming to rural development: An exploration of the socio-economic linkages of organic and non-organic farms in England, "Land Use Policy" 26(3), (2009), pp. 723-735; Demiryurek K., Analysis of information systems and communication networks for organic and conventional hazelnut producers in the Samsun province of Turkey, “Agricultural Systems” 103 (2010), pp. 444-452.

${ }^{8}$ EC, Council Regulation (EC) No 834/2007 of 28 June 2007 on organic production and labelling of organic products and repealing Regulation (EEC) No 2092/91

${ }^{9}$ Ibidem.

${ }^{10}$ Zorn A., Lippert Ch., Dabbert, S., An analysis of the risks of non-compliance with the European organic standard: A categorical analysis of farm data from a German control body, "Food Control" 30 (2013), pp. 692-699; http://ec.europa.eu/agriculture/organic/consumer-confidence/inspection-certification_en.

11 ISO, ISO/IEC 17000:2004, Conformity assessment. Vocabulary and general principles (https://law.resource.org).

${ }^{12}$ EC, Council Regulation (EC) No 834/2007, op. cit.

13 Ibidem.
} 
orous conformity assessment mechanism ${ }^{14}$. A typical organic farming certification system should be the sixth modified system according to the guide ISO/IEC Guide 67:2004 This certification system consists of following elements: (1) Determination of characteristics by inspection; (2) Review (evaluation); (3) Decision on certification; (4) Licensing; and (5) Surveillance by: (a) testing of samples, and (b) assessment of the production process. All operators during the certification process shall be subject to a physical inspection at least once per year. Moreover, in the surveillance process additional control visits and collection of samples for testing shall be carried out based on the assessment of the risk of non-compliance with the organic production rules. The risk analysis procedure in certification body should be designed based on the Regulation (EU) No 392/2013 ${ }^{16}$, which underlines two important issues: 1) the result of the risk analysis provides the basis for determining the intensity of the unannounced or announced annual inspections and visits, 2) the selection of operators to be submitted to unannounced inspections and visits is determined on the basis of the risk analysis and that these are planned according to the level of risk.

The main objective of the risk-based inspection approach is to focus resources on risky operators with regards to the frequency and intensity of controls. Generally, risk based control systems enhance the effectiveness and efficiency of controls by prioritizing and directing resources towards relatively risky operators ${ }^{17}$. The risk based-approach in certification process contributes to enhanced certification quality ${ }^{18}$. Nonetheless, it has not been specified how to conduct such risk analysis and which methods should be used for this purpose. Different CBs have different risk-based systems ${ }^{19}$. The structure and function of such risk-based inspection systems have not been deeply analyzed ${ }^{20}$.

In this study, the AHP-based models of risk-benefit assessment are developed and tested to select the best surveillance scenario and match it to a given producer. The AHP (Analytic Hierarchy Process) is a well-known and widely used method to solve a variety of decision problems ${ }^{21}$. It was developed in 1970's by the American mathematician, Thomas L. Saaty and since that time, it has gained an increasing attention in the literature. Compared with other multicriteria decision support methods such as ELECTRE, PROMETHEE\& GAIA, or VDA, the AHP is the most popular and powerful contemporary technique for decision making and expert judgments evaluation ${ }^{22}$. It has been applied in a

\footnotetext{
${ }^{14}$ Konefal J., Hatanaka M., Enacting third-party certification: A case study of science and politics in organic shrimp certification, "Journal of Rural Studies" 27 (2011), pp. 125-133.

15 ISO, ISO/IEC Guide 67:2004 Conformity assessment. Fundamentals of product certification (https://law.resource.org).

${ }^{16}$ EC, Commission Implementing Regulation (EU) No 392/2013 of 29 April 2013 amending Regulation (EC) No 889/2008 as regards the control system for organic production (http://eur-lex.europa.eu).

${ }^{17}$ Zorn A., Lippert Ch., Dabbert S., Supervising a system of approved private control bodies for certification: The case of organic farming in Germany, "Food Control" 25 (2012), pp. 525-532; Zorn A., Lippert, Ch. Dabbert, S., An analysis..., op. cit., pp. 692-699.

${ }^{18}$ Jahn G., Schramm M., Spiller A., The Reliability of Certification: Quality Labels as a Consumer Policy Tool, "Journal of Consumer Policy" 28 (2005), pp. 53-73.

${ }^{19}$ Zorn A., Lippert Ch., Dabbert S., Supervising a system..., op. cit., pp. 525-532.

${ }^{20}$ Albersmeier F., Schulze H., Jahn G., Spiller A., The reliability of third party certification in the food chain: from checklists to risk-oriented auditing, "Food Control" 20(10), (2009), pp. 927-935.

${ }^{21}$ Saaty T.L., Forman E.H., The Hierarchon. A Dictionary of Hierarchies (Analytic Hierarchy Process), RWS Publications, Pittsburgh, 1992.

${ }^{22}$ Forman E., Peniwati K., Aggregating individual judgments and priorities with the Analytic Hierarchy Process, "European Journal of Operational Research" 108 (1998), pp. 165-169.
} 
variety of fields and by many organizations, including private companies and public bodies $^{23}$. It decomposes a complex problem into hierarchical structure consisting of goal, criteria and decision variants, then elicits the relative importance / preference of these elements, and finally, calculates their weights (priorities). An element with the highest weight indicates the best solution. The AHP has been successfully applied in various areas of agricultural sciences ${ }^{24}$, for example to select an appropriate irrigation method by the farmers ${ }^{25}$ or to develop useful criteria for assessing diversification activities and to provide a ranking of different diversification activities in continuous mono-cropping of tobacco $^{26}$.

The objective of the current study is to demonstrate another potential application of the AHP in agriculture, which is certification of organic products. The research has been driven by the real need of certification bodies to develop a relatively simple and efficient method of risk assessment of clients (organic producers) applying for certification. Hence, models and templates have been created and tested by the panel of experts from the third party certification body. The procedure of the AHP-based risk assessment involves two stages: (1) deriving general models of risks (R) and benefits (B), and (2) deriving individual $\mathrm{R} / \mathrm{B}$ ratio. Such approach allows from one hand for standardization of the risk assessment process in the certification company, and from the other hand, it takes into account individual client and his specific needs and risk factors. Benefits are not specified by the regulations, yet have been identified during the discussions with the owners of the certification body. Although the risk assessment procedures do not require benefit analysis, it appeared very useful in practice and facilitated making final decision on the best variant of surveillance.

\section{THE APPLICATION OF THE AHP IN RISK-BENEFIT ASSESSMENT}

AHP decomposes a complex, and multifaceted problem into a hierarchy consisting of goal (always at the top level of hierarchy), criteria that are evaluated for their importance to the goal, and alternatives that are evaluated for how preferred they are with respect to each criterion. Criteria can be further divided into sub-criteria. A conceptual view of such a four-level hierarchy is shown in Figure 1 and is used to structure a majority of decision problems.

\footnotetext{
${ }^{23}$ Saaty T.L., Relative Measurement and Its Generalization in Decision Making. Why Pairwise Comparisons are Central in Mathematics for the Measurement of Intangible Factors, The Analytic Hierarchy/Network Process, "Rev. R. Acad. Cien. Serie A. Mat.", 102(2), (2008), pp. 253-318.

${ }^{24}$ Alphonce Ch., Application of the Analytic Hierarchy Process in Agriculture in Developing Countries, "Agricultural Systems" 53 (1997), pp. 97-112.

${ }^{25}$ Karami E., Appropriateness of farmers' adoption of irrigation methods: The application of the AHP model, "Agricultural Systems" 87 (2006), pp. 101-119.

${ }^{26}$ Chavez M.D., Berentsen PP.B.M., Oude Lansink A.G.J.M., Assessment of criteria and farming activities for tobacco diversification using the Analytical Hierarchical Process (AHP) technique, "Agricultural Systems" 111 (2012), pp. 53-62.
} 
Figure 1. The four-level AHP hierarchical model.

\section{GOAL}

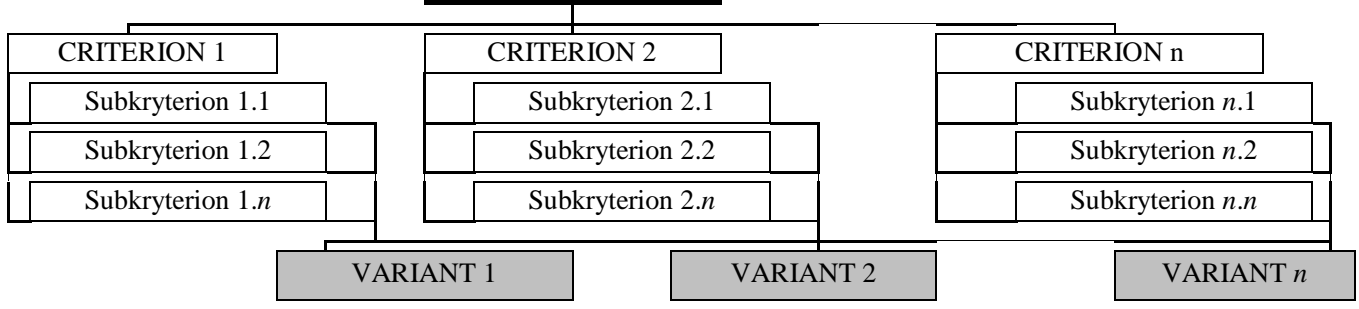

Source: own research.

Once the hierarchical model has been structured for a decision problem, decision makers or experts make pairwise comparisons for each level of the hierarchy. The use of pairwise comparisons is considered as one of the major strengths of the AHP to derive accurate ratio scale priorities, as opposed to using traditional approaches of assigning weights. Pairwise comparison is the process of comparing the relative importance, preference, or likelihood of two elements ("children") with respect to an element in the level above ("parent node"), in order to obtain priorities for the elements being compared ${ }^{27}$, for example, each criterion is pairwise compared with respect to the goal, and each sub-criterion with respect to the "parent" criterion. Pairwise comparisons are conducted for all the parent/children sets of nodes ${ }^{28}$. A "judgment" or "comparison" is the numerical demonstration of a relationship between two elements (given $\mathrm{i}$ and $\mathrm{j}$ ) that share a common parent node. The input of the comparison of each element $i$ with each element $j$ is placed in the position of $\mathrm{a}_{\mathrm{ij}}$ in a square matrix $\mathrm{A}$ in which the set of elements is compared with itself.

$$
\mathbf{A}=\left[\begin{array}{cccc}
a_{11} & a_{12} & \cdots & a_{1 n} \\
a_{21} & a_{22} & \cdots & a_{2 n} \\
\vdots & \vdots & \vdots & \vdots \\
a_{n 1} & a_{n 2} & \cdots & a_{n n}
\end{array}\right]
$$

Each judgment represents the dominance of an element in the column on the left over an element in the row on top. It therefore answers to two questions: (1) which of the two elements is more important (preferred, likely) with respect to a higher-level criterion, and (2) how strongly. The strength of dominance is measured on the bipolar nine-point fundamental scale, from " 1 " indicating the same importance (preference, likelihood) of two elements A and B, to "9" which corresponds to extreme dominance of A over B (or B over A, respectively) (Figure 2).

\footnotetext{
${ }^{27}$ Saaty T.L., Decision Making with Dependence and Feedback. The Analytic Network Process, second ed. RWS Publications, Pittsburgh, 2001.

${ }^{28}$ Prusak A., Stefanów P., AHP - analityczny proces hierarchiczny. Budowa i analiza modeli decyzyjnych krok po kroku, wyd. 1, C.H. Beck, Warszawa 2014.
} 
Figure 2. The 9-point fundamental scale.

A

\begin{tabular}{|c|c|c|c|c|c|c|c|c|}
$\begin{array}{c}\text { extreme } \\
\text { dominance } \\
\text { A }\end{array}$ & $\begin{array}{c}\text { v. strong } \\
\text { dominance } \\
\text { A }\end{array}$ & $\begin{array}{c}\text { strong } \\
\text { dominance } \\
\text { A }\end{array}$ & $\begin{array}{c}\text { weak } \\
\text { dominance } \\
\text { A }\end{array}$ & $\begin{array}{c}\text { the same } \\
\text { importance }\end{array}$ & $\begin{array}{c}\text { weak } \\
\text { dominance } \\
\text { B }\end{array}$ & $\begin{array}{c}\text { strong } \\
\text { dominance } \\
\text { B }\end{array}$ & $\begin{array}{c}\text { v. strong } \\
\text { dominance } \\
\text { B }\end{array}$ & $\begin{array}{c}\text { extreme } \\
\text { dominance } \\
\text { B }\end{array}$ \\
\hline
\end{tabular}

Source: own research.

One matrix results in "local priorities" of the children nodes with respect to the parent $^{29}$. There are several methods of deriving local priorities (also called weights), using for example: (1) dedicated software, (2) matrix multiplication, (3) geometric mean, and (4) arithmetic mean. Geometric mean is used quite frequently in the literature, although Saaty ${ }^{30}$ claimed that it should not be used for more than three elements being compared at once. In this study, matrix multiplications were used to calculate the relevant priorities. "Global priorities" of subcriteria are derived from multiplication by the priority of the criterion with respect to the goal. Mathematical basis of the whole AHP process have been provided and widely explained by Saaty ${ }^{31}$.

Having calculated priorities, the AHP requires testing consistency of judgments. The consistency test is based on the use of consistency ratio (CR), which allows a certain level of acceptable deviations $(\mathrm{CR}<0,1)$. When a pairwise comparison matrix fails to satisfy the consistency requirement, revisions are required to be made by a participating expert. The main source of inconsistency is redundancy of judgments inherent in all possible combinations of pairwise comparisons made within a group of elements, for example, nine criteria require making 36 comparisons, and causes difficulties in keeping them consistent ${ }^{32}$.

In reality, a majority of decisions are made by the team of experts rather than by a single decision maker. Thus, the AHP is often used for group settings, where members either discuss to achieve a consensus or stick to their individual judgments. Individual judgments can be aggregated is different ways of which the most widely applied are two: (1) the aggregation of individual judgments (AIJ), and (2) synthesizing individual priorities (AIP). Forman and Peniwati ${ }^{33}$ suggested that the choice of method depends on whether the group is assumed to act together as a unit or as separate individuals. If the group acts in synergy, AIJ is the most appropriate, while AIP is appropriate for the latter. In the two cases, both the geometric mean and the arithmetic mean are used for aggregating the judgments. However, the authors recommend the use of the geometric mean as more consistent with both judgments and priorities of the AHP. In the case of the group members not being of equal importance, a weighted geometric mean can be used with AIJ or weighted geometric or arithmetic mean with AIP.

Certain problems need more advanced hierarchical structures than shown above in Figure 1, with additional factors such as stakeholders and their objectives ${ }^{34}$. Most deci-

\footnotetext{
${ }^{29}$ Saaty T.L., Fundamentals of Decision Making and Priority Theory with the Analytic Hierarchy Process, Vol. VI of The AHP Series, Pittsburgh, 2006.

${ }^{30}$ Saaty T.L., Decision Making for Leaders. The Analytic Hierarchy Process for Decisions in a Complex World, RWS Publications, Pittsburgh, 2008.

${ }^{31}$ Saaty T.L., Fundamentals of Decision Making..., op. cit.

${ }^{32}$ Prusak A., Stefanów P., Badania nad właściwościami metody AHP (Operational features of the AHP method, in Polish), "Folia Oeconomica Cracoviensia" LII (2011), pp. 87-104.

${ }^{33}$ Forman E., Peniwati K., Aggregating individual..., op. cit., pp. 165-169.

${ }^{34}$ Saaty T.L., Forman E.H., The Hierarchon...., op. cit.
} 
sions also require the use of two hierarchical models: risk and benefit, as one hierarchy does not always fully reflect the problem. In such a case, final decision is based on the relation between benefits and costs, derived as a Benefit/Cost ratio (B/C) or Benefit/Risk $(\mathrm{B} / \mathrm{R})$. It is calculated as the priority of an alternative in the benefit model and the priority of respective alternative in the cost model. In other words, the most preferred alternative is that which generates highest benefits at lowest costs. The B/C ratio may adopt the following values ${ }^{35}$ :

- $B / C=1$ (benefits equal to costs or risks),

- B/C $<1$ (costs or risks exceed benefits),

- B/C $>1$ (benefits exceed costs or risks).

Despite the requirements of adopting only the risk model in the risk assessment specified by the regulation $834 / 2007^{36}$, the benefit model has been additionally provided. In reality, most decisions are the results of risk- or cost-benefit trade-offs, and merely risks or costs do not reflect the entire problem. In the organic farming, CB and producers have different goals and expectations from the certification process, and look differently at the potential risks. However, both of them are also interested in gaining benefits, which forces them to compromise between costs and quality of the certification.

\section{DESCRIPTION OF THE AHP RISK AND BENEFIT MODELS}

The AHP hierarchical models were constructed based on the review of relevant publications and official documents, and following consultation with the key informants from the third party certification body. As the decision problem concerning organic farming requires assessment of risks and benefits (despite it is called "risk assessment"), two separate hierarchical models were developed. The risk model is presented in Table 1. It contains three obligatory risk assessment criteria specified in the Regulation (EC) No 889/2008 ${ }^{37}$, specifically: (1) results of previous controls; (2) quantity of products concerned; and (3) risk for exchange of products. Other criteria that certification body can use in risk assessment process include for example: type of operator (producer, processor, importer, and distributor), structure of operator (stages of production, type of staff, and number of premises), new operators, type and value of products, complaints/denunciations received, suspicion of fraud, and other criteria (EC, 2009). In the risk model, all nonobligatory criteria mentioned in the Guidelines have been included, after the discussions and comments of the experts from the certification body. The benefit model represents advantages to the certification body and its clients, although these benefits can differ (Table 2).

\footnotetext{
${ }^{35}$ Ibidiem.

${ }^{36}$ EC, Council Regulation (EC) No 834/2007, op. cit..

${ }^{37}$ EC, Commission Regulation (EC) No 889/2008 of 5 September 2008 laying down detailed rules for the implementation of Council Regulation (EC) No 834/2007 on organic production and labelling of organic products with regard to organic production, labelling and control (http://eur-lex.europa.eu).
} 
Tabel 1. Hierarchical model of risks.

\begin{tabular}{|c|c|}
\hline & $\begin{array}{l}\text { GOAL: TO IDENTIFY THE MOST RISKY CONTROL SCENARIO BASED } \\
\text { ON THE FOLLOWING CRITERIA }\end{array}$ \\
\hline & Which criterion is more important with respect to the goal? \\
\hline 1. & CRITERION 1: Type of organic products/processes \\
\hline 1.1. & Complexity of products \\
\hline 1.1.1. & High quantity of various ingredients used \\
\hline 1.1.2. & The use of non-organic products \\
\hline 1.1 .3 . & The use of yeast and yeast products \\
\hline 1.2. & Number of suppliers of raw materials \\
\hline 1.3. & Annual production / value of products \\
\hline 1.4. & Number of production stages \\
\hline 1.5. & External origin of raw materials \\
\hline 1.6. & Participation of subcontractors in organic production \\
\hline 1.7. & Destination of products (recipients) \\
\hline 2. & CRITERION 2: Implemented and certified systems of quality management and food safety assurance \\
\hline 3 & CRITERION 3: Characteristics of enterprise \\
\hline 3.1. & Size of enterprise (number of employees) \\
\hline 3.2. & Number of departments \\
\hline 3.3. & Staff characteristics (knowledge, period of employment, etc.) \\
\hline 3.4. & Localization of enterprise (i.e. at own or others premises) \\
\hline 4. & CRITERION 4: Parallel production of conventional products \\
\hline 4.1. & The same production line for organic and conventional products \\
\hline 4.2. & Production of the same goods in two versions: organic and conventional \\
\hline 5. & CRITERION 5: Information about the producer \\
\hline 5.1. & Opinions about the producer (reputation) \\
\hline 5.2. & Informal impressions about the previous cooperation \\
\hline 5.3. & Complaints and questions received \\
\hline 5.4. & Suspicion of fraud \\
\hline 5.5 . & Failure to meet responsibilities \\
\hline 5.6. & Participation in the next stages of the food chain \\
\hline 6. & CRITERION 6: Experiences in certification of organic production \\
\hline 6.1 . & New producers (no experience in certification) \\
\hline 6.2. & The so far changes of certification bodies \\
\hline 6.3 & $\begin{array}{l}\text { Information about the producer from the Agricultural and Food Quality Inspection (public authority } \\
\text { responsible for organic farming system in Poland) }\end{array}$ \\
\hline 7. & CRITERION 7: Results of the previous controls (audits) \\
\hline 7.1 . & Number of the previous non-compliances \\
\hline 7.2 . & Assessment of corrective and preventive actions \\
\hline 7.3. & Assessment of documentation of the quality management systems \\
\hline 3.1. & Size of enterprise (number of employees) \\
\hline 3.2. & Number of departments \\
\hline 3.3. & Staff characteristics (knowledge, period of employment, etc.) \\
\hline 3.4. & Localization of enterprise (i.e. at own or others premises) \\
\hline & VARIANTS \\
\hline $\mathrm{Wh}$ & $\mathrm{h}$ variant of surveillance (control scenario) is more risky with respect to the above criteria / sub-criteria? \\
\hline 1. & VARIANT 1: Standard control plan (SCP) \\
\hline 2. & VARIANT 2: SCP + testing samples from production or SCP + additional audit \\
\hline 3. & VARIANT 3: SCP+ testing samples from production + additional audit \\
\hline
\end{tabular}

Source: own research. 
Table 2. Hierarchical model of benefits.

\begin{tabular}{|l|l|}
\hline \multicolumn{2}{|c|}{ GOAL: TO IDENTIFY THE MOST BENEFICIAL CONTROL SCENARIO BASED } \\
ON THE FOLLOWING CRITERIA:
\end{tabular}

\section{Source: own research}

Both models have the same alternative decisions available to trade-off in the process of surveillance. Short descriptions of these variants are provided in Table 3.

Table 3. Decision variants concerning the process of surveillance.

\begin{tabular}{|l|c|c|}
\hline \multicolumn{2}{|c|}{ Decision variants } & Description \\
\hline Variant 1: & $\begin{array}{c}\text { Standard control plan } \\
\text { (SCP) }\end{array}$ & $\begin{array}{c}\text { One physical inspection in the organic farming operator at the beginning of } \\
\text { the certification process. There are no other planed actions during the 12 } \\
\text { months of surveillance time. }\end{array}$ \\
$\begin{array}{c}\text { This decision variant is the cheapest from possible variants of surveillance } \\
\text { that can be chosen by CB. Probability of noncompliance that exists in the } \\
\text { organic farming operator is the highest. }\end{array}$ \\
\hline Variant 2: & $\begin{array}{c}\mathrm{SCP}+\text { testing samples } \\
\text { from production or SCP+ } \\
\text { additional audit }\end{array}$ & $\begin{array}{c}\text { One physical inspection in the organic farming operator at the beginning of } \\
\text { the certification process, plus one additional inspection or laboratory analysis } \\
\text { of the product samples. }\end{array}$ \\
\hline $\begin{array}{c}\text { SCP+ testing samples } \\
\text { from production + addi- } \\
\text { tional audit }\end{array}$ & $\begin{array}{c}\text { One physical inspection in the organic farming operator at the beginning of } \\
\text { the certification process and one additional inspection and testing of samples } \\
\text { from production in laboratory. } \\
\text { This decision variant is the most expensive from possible variants of surveil- } \\
\text { lance that can be chosen by CB. Probability of noncompliance that exists in } \\
\text { the organic farming operator is the lowest. }\end{array}$ \\
\hline
\end{tabular}

Source: own research.

\section{RESEARCH DESCRIPTION AND RESULTS}

The research was carried out in two main stages: (1) deriving general model of riskbenefit assessment; (2) deriving individual weights and B/R ratio. Stage 1 is the evaluation of criteria, subcriteria and variants in risk and benefit models and results in deriving general priorities (weights). In Stage 2, 1-5 scale points were assigned to each subcriteria 
in the risk model and the individual $\mathrm{B} / \mathrm{R}$ ratio was calculated for a selected producer. As both stages required expert judgments, data were collected in one of the organic farming $\mathrm{CB}$ operating at the Polish market. It is one of the nine authorized control bodies in organic farming that operate in Poland ${ }^{38}$. It has more than 2,000 organic farming producers under its supervision. The organization also specializes in certification of other quality food schemes, such as protected designations of origin (PDO), protected geographical indications (PGI) and traditional specialty guaranteed (TSG) specified in the regulation (EU) no 1151/2012.The organization also has one accredited laboratory in the structure. A panel of five specialists, full time employees of this certification body, participated in this study. They have theoretical and practical knowledge and experience in auditing organic farmers and processors, and are involved in risk assessment on a daily basis. As the respondents expressed their judgments independently, results have been aggregated using the AIP approach (aggregating individual priorities). The procedure is required to calculate individual weights for each expert, and then to aggregate the results using arithmetic mean.

\subsection{Stage 1. Deriving general (base) model of risk-benefit assessment}

The AHP was used to weight the importance of the criteria and subcriteria in hierarchical models of risks (Tables 4 and 5) and benefits (Tables 6 and 7), and then the preference of each variant with respect to these criteria and subcriteria. Subsequently, the optimal variant appears as one fulfilling to the highest degree the most important criteria and the goal. The opinions were expressed by pairwise comparisons using the nine-point fundamental scale, for example, the experts answered the following questions:

- Which criterion is more important with respect to the goal (Goal $=$ To identify the most risky or beneficial control scenario)?

- Which subcriterion is more important with respect to the relevant criterion?

- Which variant of surveillance (control scenario) is preferred with respect to the criteria/subcriteria?

Local priorities (weights) have been calculated using the matrix multiplications and a spreadsheet. All values shown in these tables represent numbers from all the experts aggregated by arithmetic mean. Normalized global weights of the subcriteria have been derived from multiplication of their local weights by the priority of the relevant criterion with respect to the goal. The grey column called Importance in Table 4 and 6 reflects the degree to which particular factors (criteria and subcriteria) apply to the customer (organic producer) who will be evaluated in stage 2 at the 5-point scale. In general model, all values in this column are equal to "1", which can be translated as "neutral". In individual model, the subsequent values of 2-5 are used to indicate the degree of importance of each factor with respect to a selected customer being the subject of risk assessment. Since Modified local (global) weights shown in the next columns are derived as multiplication of Importance by Local (global) weights, in general model both numbers are the same. Subsequently, global priorities for decision variants and $B / R$ ratio indicate which control scenario is the most preferred in general, while in stage 2 they will specify which scenario is optimal for a selected customer.

Tables 4 and 5 present all priorities for risks (separate tables for criteria and variants to

${ }^{38}$ IJHAR-S, http://www.ijhar-s.gov.pl/organic-farming.html. 
increase clarity).The results show that in general, the most risky control scenario is variant 1 - Standard Control Plan $(\mathrm{SCP})(\mathrm{W}(\mathrm{R}) \mathrm{V} 1=0,5625)$, while variant $3(\mathrm{SCP}+$ testing of samples from production + additional audit) appears to be of lowest risk $(\mathrm{R}(\mathrm{R}) \mathrm{V} 3=0,1845)$. Another type of information that can be read from this table is the level of risk of particular factors (criteria and subcriteria) in the process of risk assessment. Parallel production of conventional products received the highest risk priority from all the criteria $(\mathrm{W}(\mathrm{R}) 2=0,3025)$. Under this risk, two subcriteria have been distinguished in the hierarchical model: having the same production line for organic and conventional products $(\mathrm{W}(\mathrm{R}) 2.1)$ and production of the same goods in organic and conventional versions $(\mathrm{W}(\mathrm{R}) 2.2)$. Both of them received the highest global priorities of all 28 subcriteria presented in the risk model $(\mathrm{W}(\mathrm{R}) 2.1=0,1832, \mathrm{~W}(\mathrm{R}) 2.2=0,1193)$. Such numbers indicate that these factors are of utmost importance in risk assessment procedure, as the risk of noncompliance is higher in companies with parallel production of conventional and organic goods.

Tables 6 and 7 shows general priorities for benefits (as above, individual tables for criteria and variants), while Table 8 compares risks (R) with benefits (B) and calculates the $\mathrm{B} / \mathrm{R}$ ratio for decision variants. In terms of advantages, the differences between the three control variants were not as sharp as in case of risks. Variant 3 (with the lowest risk priority) received at the same time the highest weight for benefits $(\mathrm{W}(\mathrm{B}) \mathrm{V} 3=0,4183)$, and consequently, the highest $B / R$ ratio $(\mathrm{W}(\mathrm{B} / \mathrm{R}) \mathrm{V} 3=2,2672)$. As Table 6provides information on benefits represented by particular factors, reliability of the certification process was indicated as the most favorable criterion, whose weight accounts for over $50 \%$ of the main goal (W(B)3=0,5182). Under this criterion, increased trust to certified products (W(B)3.2) and minimization of costs of improper decisions (W(B)3.3) appeared to have the greatest meaning, also in terms of the global weights $(\mathrm{W}(\mathrm{B}) 3=0,2709, \mathrm{~W}(\mathrm{~B}) 3.3=0,2910)$.

Table 4. General priorities for criteria in the risk model.

\begin{tabular}{|c|c|c|c|c|c|c|c|}
\hline Criteria & Codes & $\begin{array}{c}\text { Local } \\
\text { weights }\end{array}$ & $\begin{array}{c}\text { Global } \\
\text { weights } \\
\text { normalized }\end{array}$ & Importance & $\begin{array}{c}\text { Modified } \\
\text { local } \\
\text { weights }\end{array}$ & \begin{tabular}{|c|} 
Modified \\
local \\
weights \\
normalized
\end{tabular} & $\begin{array}{c}\text { Modified } \\
\text { global } \\
\text { weights } \\
\text { normalized }\end{array}$ \\
\hline $\begin{array}{l}\text { Type of organic products / } \\
\text { processes }\end{array}$ & $\mathrm{W}(\mathrm{R}) 1$ & 0.1512 & 0.1512 & 1 & 0.1512 & 0.1512 & 0.1512 \\
\hline Complexity of products & $\mathrm{W}(\mathrm{R}) 1.1$ & 0.2560 & 0.0387 & 1 & 0.2560 & 0.2561 & 0.0387 \\
\hline $\begin{array}{l}\text { High quantity of various } \\
\text { ingredients used }\end{array}$ & $\mathrm{W}(\mathrm{R}) 1.1 .1$ & 0.2698 & 0.0104 & 1 & 0.2698 & 0.2697 & 0.0104 \\
\hline $\begin{array}{l}\text { The use of non-organic } \\
\text { products - annex IX }\end{array}$ & $\mathrm{W}(\mathrm{R}) 1.1 .2$ & 0.5552 & 0.0215 & 1 & 0.5552 & 0.5551 & 0.0215 \\
\hline $\begin{array}{l}\text { The use of yeast and yeast } \\
\text { products - annex VIII }\end{array}$ & $\mathrm{W}(\mathrm{R}) 1.1 .3$ & 0.1752 & 0.0068 & 1 & 0.1752 & 0.1752 & 0.0068 \\
\hline $\begin{array}{l}\text { Number of suppliers of raw } \\
\text { materials }\end{array}$ & $\mathrm{W}(\mathrm{R}) 1.2$ & 0.0914 & 0.0138 & 1 & 0.0914 & 0.0914 & 0.0138 \\
\hline $\begin{array}{l}\text { Annual production / value of } \\
\text { products }\end{array}$ & $\mathrm{W}(\mathrm{R}) 1.3$ & 0.0478 & 0.0072 & 1 & 0.0478 & 0.0478 & 0.0072 \\
\hline Number of production stages & $\mathrm{W}(\mathrm{R}) 1.4$ & 0.1248 & 0.0189 & 1 & 0.1248 & 0.1248 & 0.0189 \\
\hline $\begin{array}{l}\text { External origin of raw mate- } \\
\text { rials }\end{array}$ & $\mathrm{W}(\mathrm{R}) 1.5$ & 0.1702 & 0.0257 & 1 & 0.1702 & 0.1702 & 0.0257 \\
\hline $\begin{array}{l}\text { Participation of subcontrac- } \\
\text { tors in organic production }\end{array}$ & W(R)1.6 & 0.2354 & 0.0356 & 1 & 0.2354 & 0.2354 & 0.0356 \\
\hline
\end{tabular}




\begin{tabular}{|c|c|c|c|c|c|c|c|}
\hline $\begin{array}{|lll|}\begin{array}{l}\text { Destination } \\
\text { (recipients) }\end{array} & \text { of products } \\
\end{array}$ & $\mathrm{W}(\mathrm{R}) 1.7$ & 0.0742 & 0.0112 & 1 & 0.0742 & 0.0742 & 0.0112 \\
\hline $\begin{array}{l}\text { Parallel production of con- } \\
\text { ventional products }\end{array}$ & $\mathrm{W}(\mathrm{R}) 2$ & 0.3025 & 0.3025 & 1 & 0.3025 & 0.3025 & 0.3025 \\
\hline $\begin{array}{l}\text { The same production line for } \\
\text { organic and conventional } \\
\text { products }\end{array}$ & $\mathrm{W}(\mathrm{R}) 2.1$ & 0.6056 & 0.1832 & 1 & 0.6056 & 0.6056 & 0.1832 \\
\hline $\begin{array}{l}\text { Production of the same } \\
\text { goods in organic and con- } \\
\text { ventional versions }\end{array}$ & $\mathrm{W}(\mathrm{R}) 2.2$ & 0.3944 & 0.1193 & 1 & 0.3944 & 0.3944 & 0.1193 \\
\hline Characteristics of enterprise & $\mathrm{W}(\mathrm{R}) 3$ & 0.0683 & 0.0683 & 1 & 0.0683 & 0.0683 & 0.0683 \\
\hline \begin{tabular}{|l|} 
Size of enterprise (number of \\
employees)
\end{tabular} & W(R)3.1 & 0.1318 & 0.0090 & 1 & 0.1318 & 0.1319 & 0.0090 \\
\hline Number of departments & $\mathrm{W}(\mathrm{R}) 3.2$ & 0.1382 & 0.0094 & 1 & 0.1382 & 0.1383 & 0.0094 \\
\hline \begin{tabular}{|l|} 
Staff characteristics \\
(knowledge, period of em- \\
ployment, etc.)
\end{tabular} & $\mathrm{W}(\mathrm{R}) 3.3$ & 0.5348 & 0.0365 & 1 & 0.5348 & 0.5350 & 0.0365 \\
\hline \begin{tabular}{|l|} 
Localization of enterprise \\
(i.e. at own or others premis- \\
es)
\end{tabular} & $\mathrm{W}(\mathrm{R}) 3.4$ & 0.1948 & 0.0133 & 1 & 0.1948 & 0.1949 & 0.0133 \\
\hline $\begin{array}{l}\text { Implemented and certified } \\
\text { systems of quality manage- } \\
\text { ment and food safety assur- } \\
\text { ance }\end{array}$ & $\mathrm{W}(\mathrm{R}) 4$ & 0.0555 & 0.0555 & 1 & 0.0555 & 0.0555 & 0.0555 \\
\hline $\begin{array}{l}\text { Information about the pro- } \\
\text { ducer }\end{array}$ & $\mathrm{W}(\mathrm{R}) 5$ & 0.0966 & 0.0966 & 1 & 0.0966 & 0.0966 & 0.0966 \\
\hline $\begin{array}{l}\text { Opinions about the producer } \\
\text { (reputation) }\end{array}$ & $\mathrm{W}(\mathrm{R}) 5.1$ & 0.0518 & 0.0050 & 1 & 0.0518 & 0.0518 & 0.005 \\
\hline $\begin{array}{l}\text { Informal impressions about } \\
\text { the previous cooperation }\end{array}$ & $\mathrm{W}(\mathrm{R}) 5.2$ & 0.0704 & 0.0068 & 1 & 0.0704 & 0.0704 & 0.0068 \\
\hline \begin{tabular}{|l|}
$\begin{array}{l}\text { Complaints and questions } \\
\text { received }\end{array}$ \\
\end{tabular} & $\mathrm{W}(\mathrm{R}) 5.3$ & 0.2194 & 0.0212 & 1 & 0.2194 & 0.2193 & 0.0212 \\
\hline Suspicion of fraud & $\mathrm{W}(\mathrm{R}) 5.4$ & 0.3244 & 0.0313 & 1 & 0.3244 & 0.3242 & 0.0313 \\
\hline \begin{tabular}{|l|} 
Failure to meet responsibili- \\
ties
\end{tabular} & $\mathrm{W}(\mathrm{R}) 5.5$ & 0.2454 & 0.0237 & 1 & 0.2454 & 0.2453 & 0.0237 \\
\hline $\begin{array}{l}\text { Participation in the next } \\
\text { stages of the food chain }\end{array}$ & $\mathrm{W}(\mathrm{R}) 5.6$ & 0.0892 & 0.0086 & 1 & 0.0892 & 0.0891 & 0.0086 \\
\hline $\begin{array}{l}\text { Experiences in certification } \\
\text { of organic production }\end{array}$ & $\mathrm{W}(\mathrm{R}) 6$ & 0.1164 & 0.1164 & 1 & 0.1164 & 0.1164 & 0.1164 \\
\hline $\begin{array}{l}\text { New producers (no experi- } \\
\text { ence in certification) }\end{array}$ & $\mathrm{W}(\mathrm{R}) 6.1$ & 0.1750 & 0.0204 & 1 & 0.1750 & 0.1750 & 0.0204 \\
\hline $\begin{array}{l}\text { The so far changes of certifi- } \\
\text { cation bodies }\end{array}$ & $\mathrm{W}(\mathrm{R}) 6.2$ & 0.3190 & 0.0371 & 1 & 0.3190 & 0.3190 & 0.0371 \\
\hline $\begin{array}{l}\text { Information about the pro- } \\
\text { ducer from Agric. and Food } \\
\text { Quality Insp. }\end{array}$ & W(R)6.3 & 0.5060 & 0.0589 & 1 & 0.5060 & 0.5060 & 0.0589 \\
\hline $\begin{array}{l}\text { Results of the previous } \\
\text { controls (audits) }\end{array}$ & $\mathrm{W}(\mathrm{R}) 7$ & 0.2096 & 0.2096 & 1 & 0.2096 & 0.2096 & 0.2096 \\
\hline $\begin{array}{l}\text { Number of the previous non- } \\
\text { compliances }\end{array}$ & $\mathrm{W}(\mathrm{R}) 7.1$ & 0.5140 & 0.1077 & 1 & 0.5140 & 0.5141 & 0.1078 \\
\hline \begin{tabular}{|l|}
$\begin{array}{l}\text { Assessment of corrective and } \\
\text { preventive actions }\end{array}$ \\
\end{tabular} & $\mathrm{W}(\mathrm{R}) 7.2$ & 0.3832 & 0.0803 & 1 & 0.3832 & 0.3833 & 0.0803 \\
\hline
\end{tabular}




\begin{tabular}{|l|l|l|l|l|l|l|l|}
\hline $\begin{array}{l}\text { Assessment of documenta- } \\
\text { tion of the quality manage- } \\
\text { ment systems }\end{array}$ & $\mathrm{W}(\mathrm{R}) 7.3$ & 0.1026 & 0.0215 & 1 & 0.1026 & 0.1026 & 0.0215 \\
\hline
\end{tabular}

Source: own research.

Table 5. General priorities for variants in the risk model.

\begin{tabular}{|c|c|c|c|c|c|c|}
\hline \multirow[t]{2}{*}{ Criteria } & \multicolumn{3}{|c|}{ Local weights } & \multicolumn{3}{|c|}{ Global weights } \\
\hline & VAR. 1 & VAR. 2 & VAR. 3 & VAR. 1 & VAR. 2 & VAR. 3 \\
\hline \multicolumn{7}{|l|}{$\begin{array}{l}\text { Type of organic products / pro- } \\
\text { cesses }\end{array}$} \\
\hline \multicolumn{7}{|l|}{ Complexity of products } \\
\hline $\begin{array}{l}\text { High quantity of various ingredi- } \\
\text { ents used }\end{array}$ & 0.6048 & 0.1697 & 0.2255 & 0.0063 & 0.0018 & 0.0023 \\
\hline $\begin{array}{l}\text { The use of non-organic products - } \\
\text { annex IX }\end{array}$ & 0.5908 & 0.2429 & 0.1663 & 0.0127 & 0.0052 & 0.0036 \\
\hline $\begin{array}{l}\text { The use of yeast and yeast prod- } \\
\text { ucts - annex VIII }\end{array}$ & 0.5857 & 0.2487 & 0.1655 & 0.0040 & 0.0017 & 0.0011 \\
\hline $\begin{array}{l}\text { Number of suppliers of raw } \\
\text { materials }\end{array}$ & 0.5851 & 0.2552 & 0.1596 & 0.0081 & 0.0035 & 0.0022 \\
\hline $\begin{array}{l}\text { Annual production / value of } \\
\text { products }\end{array}$ & 0.3333 & 0.3333 & 0.3333 & 0.0024 & 0.0024 & 0.0024 \\
\hline Number of production stages & 0.3333 & 0.3333 & 0.3333 & 0.0063 & 0.0063 & 0.0063 \\
\hline External origin of raw materials & 0.5793 & 0.2555 & 0.1652 & 0.0149 & 0.0066 & 0.0042 \\
\hline $\begin{array}{l}\text { Participation of subcontractors in } \\
\text { organic production }\end{array}$ & 0.5587 & 0.2702 & 0.1711 & 0.0199 & 0.0096 & 0.0061 \\
\hline $\begin{array}{l}\text { Destination of products (reci- } \\
\text { pients) }\end{array}$ & 0.5209 & 0.2824 & 0.1966 & 0.0058 & 0.0032 & 0.0022 \\
\hline \multicolumn{7}{|l|}{$\begin{array}{l}\text { Parallel production of conven- } \\
\text { tional products }\end{array}$} \\
\hline $\begin{array}{l}\text { The same production line for } \\
\text { organic and conventional prod- } \\
\text { ucts }\end{array}$ & 0.6067 & 0.2422 & 0.1511 & 0.1111 & 0.0444 & 0.0277 \\
\hline \begin{tabular}{|l|} 
Production of the same goods in \\
organic and conventional versions
\end{tabular} & 0.5982 & 0.2509 & 0.1509 & 0.0714 & 0.0299 & 0.0180 \\
\hline \multicolumn{7}{|l|}{ Characteristics of enterprise } \\
\hline $\begin{array}{l}\text { Size of enterprise (number of } \\
\text { employees) }\end{array}$ & 0.5443 & 0.2595 & 0.1962 & 0.0049 & 0.0023 & 0.0018 \\
\hline Number of departments & 0.5152 & 0.2755 & 0.2093 & 0.0048 & 0.0026 & 0.0020 \\
\hline $\begin{array}{l}\text { Staff characteristics (knowledge, } \\
\text { period of employment, etc.) }\end{array}$ & 0.5248 & 0.2744 & 0.2008 & 0.0192 & 0.0100 & 0.0073 \\
\hline $\begin{array}{l}\text { Localization of enterprise (i.e. at } \\
\text { own or others premises) }\end{array}$ & 0.5708 & 0.2641 & 0.1651 & 0.0076 & 0.0035 & 0.0022 \\
\hline $\begin{array}{l}\text { Implemented and certified sys- } \\
\text { tems of quality management and } \\
\text { food safety assurance }\end{array}$ & 0.3659 & 0.4091 & 0.2250 & 0.0203 & 0.0227 & 0.0125 \\
\hline \multicolumn{7}{|l|}{ Information about the producer } \\
\hline $\begin{array}{l}\text { Opinions about the producer } \\
\text { (reputation) }\end{array}$ & 0.4913 & 0.2455 & 0.2632 & 0.0025 & 0.0012 & 0.0013 \\
\hline $\begin{array}{l}\text { Informal impressions about the } \\
\text { previous cooperation }\end{array}$ & 0.4914 & 0.2427 & 0.2659 & 0.0033 & 0.0017 & 0.0018 \\
\hline
\end{tabular}




\begin{tabular}{|c|c|c|c|c|c|c|}
\hline $\begin{array}{l}\text { Complaints and questions re- } \\
\text { ceived }\end{array}$ & 0.5241 & 0.2283 & 0.2475 & 0.0111 & 0.0048 & 0.0052 \\
\hline Suspicion of fraud & 0.5295 & 0.2260 & 0.2446 & 0.0166 & 0.0071 & 0.0077 \\
\hline Failure to meet responsibilities & 0.5631 & 0.2027 & 0.2342 & 0.0133 & 0.0048 & 0.0056 \\
\hline $\begin{array}{l}\text { Participation in the next stages of } \\
\text { the food chain }\end{array}$ & 0.5699 & 0.2026 & 0.2275 & 0.0049 & 0.0017 & 0.0020 \\
\hline \multicolumn{7}{|l|}{$\begin{array}{l}\text { Experiences in certification of } \\
\text { organic production }\end{array}$} \\
\hline $\begin{array}{l}\text { New producers (no experience in } \\
\text { certification) }\end{array}$ & 0.5551 & 0.2712 & 0.1737 & 0.0113 & 0.0055 & 0.0035 \\
\hline $\begin{array}{l}\text { The so far changes of certification } \\
\text { bodies }\end{array}$ & 0.5868 & 0.2481 & 0.1651 & 0.0218 & 0.0092 & 0.0061 \\
\hline $\begin{array}{l}\text { Information about the producer } \\
\text { from Agric. and Food Quality } \\
\text { Insp. }\end{array}$ & 0.5992 & 0.2413 & 0.1595 & 0.0353 & 0.0142 & 0.0094 \\
\hline \multicolumn{7}{|l|}{$\begin{array}{l}\text { Results of the previous controls } \\
\text { (audits) }\end{array}$} \\
\hline $\begin{array}{l}\text { Number of the previous non- } \\
\text { compliances }\end{array}$ & 0.6025 & 0.2435 & 0.1540 & 0.0649 & 0.0262 & 0.0166 \\
\hline $\begin{array}{l}\text { Assessment of corrective and } \\
\text { preventive actions }\end{array}$ & 0.5693 & 0.2018 & 0.2289 & 0.0457 & 0.0162 & 0.0184 \\
\hline $\begin{array}{l}\text { Assessment of documentation of } \\
\text { the quality management systems }\end{array}$ & 0.5631 & 0.2065 & 0.2304 & 0.0121 & 0.0044 & 0.0050 \\
\hline \multirow{2}{*}{\multicolumn{4}{|c|}{ Codes: }} & 0.5625 & 0.2527 & 0.1845 \\
\hline & & & & $\mathrm{W}(\mathrm{R}) \mathrm{V} 1$ & $\mathrm{~W}(\mathrm{R}) \mathrm{V} 2$ & $\mathrm{~W}(\mathrm{R}) \mathrm{V} 3$ \\
\hline
\end{tabular}

Source: own research.

Table 6. General priorities for criteria in the benefit model.

\begin{tabular}{|l|c|c|c|c|c|c|c|}
\hline Criteria & Codes & $\begin{array}{c}\text { Local } \\
\text { weights }\end{array}$ & $\begin{array}{c}\text { Global } \\
\text { weights } \\
\text { normalized }\end{array}$ & Importance & $\begin{array}{c}\text { Modified } \\
\text { local } \\
\text { weights }\end{array}$ & $\begin{array}{c}\text { Modified } \\
\text { local } \\
\text { weights } \\
\text { normalized }\end{array}$ & $\begin{array}{c}\text { Modified } \\
\text { global } \\
\text { weights } \\
\text { normalized }\end{array}$ \\
\hline $\begin{array}{l}\text { Costs of the certification } \\
\text { process }\end{array}$ & W(B)1 & 0.2410 & 0.241 & 1 & 0.2410 & 0.0803 & 0.0803 \\
\hline $\begin{array}{l}\text { Minimization of the costs of } \\
\text { taking and analyzing samples } \\
\text { of the products }\end{array}$ & W(B)1.1 & 0.2602 & 0.0627 & 1 & 0.2602 & 0.2601 & 0.0627 \\
\hline $\begin{array}{l}\text { Minimization of the control } \\
\text { costs }\end{array}$ & W(B)1.2 & 0.3344 & 0.0806 & 1 & 0.3344 & 0.3343 & 0.0806 \\
\hline $\begin{array}{l}\text { Minimization of general } \\
\text { expenses (i.e. office) }\end{array}$ & W(B)1.3 & 0.4056 & 0.0977 & 1 & 0.4056 & 0.4055 & 0.0977 \\
\hline Customer satisfaction & W(B)2 & 0.2410 & 0.2410 & 1 & 0.2410 & 0.0803 & 0.0803 \\
\hline $\begin{array}{l}\text { Reduced "oppressiveness" of } \\
\text { the control process }\end{array}$ & W(B)2.1 & 0.2058 & 0.0496 & 1 & 0.2058 & 0.2059 & 0.0496 \\
\hline $\begin{array}{l}\text { Increased chances for certifica- } \\
\text { tion }\end{array}$ & W(B)2.2 & 0.2714 & 0.0654 & 1 & 0.2714 & 0.2715 & 0.0654 \\
\hline $\begin{array}{l}\text { Reduced costs incurred by the } \\
\text { customer }\end{array}$ & W(B)2.3 & 0.5224 & 0.1259 & 1 & 0.5224 & 0.5226 & 0.1259 \\
\hline $\begin{array}{l}\text { Reliability of the certification } \\
\text { process }\end{array}$ & W(B)3 & 0.5182 & 0.5182 & 1 & 0.5182 & 0.1727 & 0.1727 \\
\hline $\begin{array}{l}\text { Increased value of the "brand" } \\
\text { of certification body }\end{array}$ & W(B)3.1 & 0.1862 & 0.0965 & 1 & 0.1862 & 0.1862 & 0.0965 \\
\hline
\end{tabular}




\begin{tabular}{|l|c|c|c|c|c|c|c|}
\hline Criteria & Codes & $\begin{array}{c}\text { Local } \\
\text { weights }\end{array}$ & $\begin{array}{c}\text { Global } \\
\text { weights } \\
\text { normalized }\end{array}$ & Importance & $\begin{array}{c}\text { Modified } \\
\text { local } \\
\text { weights }\end{array}$ & $\begin{array}{c}\text { Modified } \\
\text { local } \\
\text { weights } \\
\text { normalized }\end{array}$ & $\begin{array}{c}\text { Modified } \\
\text { global } \\
\text { weights } \\
\text { normalized }\end{array}$ \\
\hline $\begin{array}{l}\text { Increased trust to certified } \\
\text { products }\end{array}$ & W(B)3.2 & 0.5228 & 0.2709 & 1 & 0.5228 & 0.5228 & 0.2709 \\
\hline $\begin{array}{l}\text { Minimization of costs of } \\
\text { improper decisions }\end{array}$ & W(B)3.3 & 0.2910 & 0.1508 & 1 & 0.2910 & 0.291 & 0.1508 \\
\hline $\begin{array}{l}\text { Minimization of potential } \\
\text { claims }\end{array}$ & W(B)3.4 & 0.2033 & 0.0307 & 1 & 0.2033 & 0.2033 & 0.0307 \\
\hline $\begin{array}{l}\text { Minimization of the possibility } \\
\text { to revoke the certificate }\end{array}$ & W(B)3.5 & 0.7967 & 0.1201 & 1 & 0.7967 & 0.7967 & 0.1201 \\
\hline
\end{tabular}

Source: own research.

Table 7. General priorities for variants in the benefit model.

\begin{tabular}{|c|c|c|c|c|c|c|}
\hline \multirow[t]{2}{*}{ Criteria } & \multicolumn{3}{|c|}{ Local weights } & \multicolumn{3}{|c|}{ Global weights } \\
\hline & VAR. 1 & VAR. 2 & VAR. 3 & VAR. 1 & VAR. 2 & VAR. 3 \\
\hline \multicolumn{7}{|l|}{ Costs of the certification process } \\
\hline $\begin{array}{l}\text { Minimization of the costs of taking } \\
\text { and analyzing samples of the prod- } \\
\text { ucts }\end{array}$ & 0.5612 & 0.2187 & 0.2201 & 0.0352 & 0.0137 & 0.0138 \\
\hline Minimization of the control costs & 0.6081 & 0.1922 & 0.1997 & 0.0490 & 0.0155 & 0.0161 \\
\hline $\begin{array}{l}\text { Minimization of general expenses } \\
\text { (i.e. office) }\end{array}$ & 0.6624 & 0.2369 & 0.1007 & 0.0647 & 0.0231 & 0.0098 \\
\hline \multicolumn{7}{|l|}{ Customer satisfaction } \\
\hline $\begin{array}{l}\text { Reduced "oppressiveness" of the } \\
\text { control process }\end{array}$ & 0.7448 & 0.1944 & 0.0608 & 0.0369 & 0.0096 & 0.0030 \\
\hline Increased chances for certification & 0.4750 & 0.2047 & 0.3203 & 0.0311 & 0.0134 & 0.0209 \\
\hline $\begin{array}{l}\text { Reduced costs incurred by the } \\
\text { customer }\end{array}$ & 0.5736 & 0.2137 & 0.2127 & 0.0722 & 0.0269 & 0.0268 \\
\hline \multicolumn{7}{|l|}{\begin{tabular}{|l}
$\begin{array}{l}\text { Reliability of the certification } \\
\text { process }\end{array}$ \\
\end{tabular}} \\
\hline $\begin{array}{l}\text { Increased value of the "brand" of } \\
\text { certification body }\end{array}$ & 0.1039 & 0.2690 & 0.6271 & 0.0100 & 0.0260 & 0.0605 \\
\hline Increased trust to certified products & 0.1844 & 0.2173 & 0.5983 & 0.0500 & 0.0589 & 0.1621 \\
\hline \multicolumn{7}{|l|}{$\begin{array}{l}\text { Minimization of costs of improper } \\
\text { decisions }\end{array}$} \\
\hline Minimization of potential claims & 0.1157 & 0.2529 & 0.6315 & 0.0036 & 0.0078 & 0.0194 \\
\hline $\begin{array}{l}\text { Minimization of the possibility to } \\
\text { revoke the certificate }\end{array}$ & 0.0619 & 0.2232 & 0.7150 & 0.0074 & 0.0268 & 0.0859 \\
\hline \multirow{2}{*}{\multicolumn{4}{|c|}{ Codes: }} & 0.3601 & 0.2217 & 0.4183 \\
\hline & & & & $\mathrm{W}(\mathrm{B}) \mathrm{V} 1$ & $\mathrm{~W}(\mathrm{~B}) \mathrm{V} 2$ & $\mathrm{~W}(\mathrm{~B}) \mathrm{V} 3$ \\
\hline
\end{tabular}

Source: own research. 
Table 8. B/R ratio for general model.

\begin{tabular}{|l|c|c|c|}
\hline Risk/Benefit & $\begin{array}{c}\text { Standard control plan } \\
\text { (SCP) }\end{array}$ & $\begin{array}{c}\text { SCP + testing of samples from pro- } \\
\text { duction orSCP + additional audit }\end{array}$ & $\begin{array}{c}\text { SCP+ testing of samples from } \\
\text { production + additional audit }\end{array}$ \\
\hline $\mathrm{B}$ & 0.3601 & 0.2217 & 0.4183 \\
\hline $\mathrm{R}$ & 0.5625 & 0.2527 & 0.1845 \\
\hline $\mathrm{B} / \mathrm{R}$ & 0.6402 & 0.8773 & 2.2672 \\
\hline
\end{tabular}

Source: own research.

Checking consistency is a very important step of the AHP. The consistency report for risk and benefit criteria is provided in Table 9. As it was explained above, the consistency ratio (CR) proposed by Saaty $^{39}$ allows maximum inconsistency of $0.10(10 \%)$. However, adopting such a strict level of acceptable inconsistency of pairwise judgments has been criticized as too rigorous ${ }^{40}$. As consistency test is prepared for each pairwise comparison matrix and for each participant individually, the consistency report includes only the criteria. The results show satisfactory results of consistency test for majority of experts, except for the judgment of expert five in the risk model $(\mathrm{CR}=0.60)$, which has been excluded from the analysis. In benefit model, in case of two experts $C R=0.28$. Although it exceeded the acceptable level of $\mathrm{CR}=0.10$, it was considered satisfactory due to large number of comparisons.

Table 9. B/R ratio for general model.

\begin{tabular}{|l|c|c|c|c|c|}
\hline Respondents: & $\mathbf{1}$ & $\mathbf{2}$ & $\mathbf{3}$ & $\mathbf{4}$ & $\mathbf{5}$ \\
\hline CR in Risk model: & 0.11 & 0.12 & 0.21 & 0.11 & 0.60 \\
\hline CR in Benefit model: & 0.00 & 0.08 & 0.28 & 0.13 & 0.28 \\
\hline
\end{tabular}

Source: own research.

Stage 1 produces the base, "universal" results that can be applied for any organic producer being the potential client of the certification body. The priorities (weights) derived by the group of experts using the above hierarchical models and templates can be then "individualized" by indicating relevance of particular factors to the selected organic producer. This procedure is reported in stage 2 .

\subsection{Stage 1. Deriving individual model of risk-benefit assessment}

In Stage 2, the relevance of surveillance criteria (and sub-criteria) is assessed for each client individually, using the 5-point scale from "1" - neutral, to "5" - high importance. In this study, only risk model was taken for individual analysis. It is justified by the fact that unlike risks, benefits are analyzed from the point of view of the certification company, with no relevance to the particular clients. However, as benefits influence the final decision, their scores have been taken from the general model. An employee of the certification body assessed the relevance of risks of one randomly chosen client. The client was a small fruit and vegetable processing company operating on a local market. The company started an organic farming production one year before the assessment with two organic

\footnotetext{
${ }^{39}$ Saaty T.L., The Analytic Hierarchy Process: Planning, Priority Setting, Resource Allocation, McGraw-Hill, 2nd edition, New York, 1980.

40 Apostolou B., Hassel J.M., An empirical examination of the sensitivity of the analytic hierarchy process to departures from recommended consistency ratios, "Mathematical and Computer Modeling", 4/5, 1993, pp. 163-170.
} 
products: organic strawberry jam and fermented rye flour, which is used to produce soups. Organic farming production in this company has marginal importance comparing to conventional production. A majority of data needed to assess the relevance of risks was available in the certification body records. Missing data was mainly the 'soft' risk factors included in the risk model, such as staff characteristics, reputation of a producer, informal impressions about the previous cooperation, suspicion of fraud, and assessment of documentation of the quality management systems. Information about these factors has been provided by the experts, however, they stressed that in the process of implementation of the AHP risk-benefit models methods of recording such data needs to be further developed and standardized. Relevance of the risk factors and the new modified priorities for criteria and variants are shown in Table 10 and 11.Most risks have been judged as no relevant (neutral), causing no change in global weights. Risks of greatest relevance ("5") to the organic producer include the same production line for organic and conventional products, staff characteristics, new producer with no experience in previous certification, and (scored as "4") production of the same goods in organic and conventional versions.

Table 10. Individual priorities for criteria in the risk model.

\begin{tabular}{|l|c|c|c|c|c|c|c|}
\hline Criteria & Codes & $\begin{array}{c}\text { Local } \\
\text { weights }\end{array}$ & $\begin{array}{c}\text { Global } \\
\text { weights } \\
\text { normalized }\end{array}$ & Importance & $\begin{array}{c}\text { Modified } \\
\text { local } \\
\text { weights }\end{array}$ & $\begin{array}{c}\text { Modified } \\
\text { local } \\
\text { weights } \\
\text { normalized }\end{array}$ & $\begin{array}{c}\text { Modified } \\
\text { global } \\
\text { weights } \\
\text { normalized }\end{array}$ \\
\hline $\begin{array}{l}\text { Type of organic products } \\
\text { processes }\end{array}$ & $\mathrm{W}(\mathrm{R}) 1$ & 0.1512 & 0.1512 & 1 & 0.1512 & 0.1512 & 0.1512 \\
\hline $\begin{array}{l}\text { Complexity of products } \\
\text { High quantity of various } \\
\text { ingredients used }\end{array}$ & $\mathrm{W}(\mathrm{R}) 1.1$ & 0.2560 & 0.0387 & 1 & 0.2560 & 0.1587 & 0.0240 \\
\hline $\begin{array}{l}\text { The use of non-organic } \\
\text { products - annex IX }\end{array}$ & 0.2698 & 0.0104 & 2 & 0.5396 & 0.4249 & 0.0102 \\
\hline $\begin{array}{l}\text { The use of yeast and yeast } \\
\text { products - annex VIII }\end{array}$ & $\mathrm{W}(\mathrm{R}) 1.1 .3$ & 0.1752 & 0.0068 & 1 & 0.1752 & 0.1380 & 0.0033 \\
\hline $\begin{array}{l}\text { Number of suppliers of } \\
\text { raw materials }\end{array}$ & $\mathrm{W}(\mathrm{R}) 1.2$ & 0.0914 & 0.0138 & 1 & 0.0914 & 0.0567 & 0.0086 \\
\hline $\begin{array}{l}\text { Annual production / value } \\
\text { of products }\end{array}$ & $\mathrm{W}(\mathrm{R}) 1.3$ & 0.0478 & 0.0072 & 1 & 0.0478 & 0.0296 & 0.0045 \\
\hline $\begin{array}{l}\text { Number of production } \\
\text { stages }\end{array}$ & $\mathrm{W}(\mathrm{R}) 1.4$ & 0.1248 & 0.0189 & 2 & 0.2496 & 0.1547 & 0.0234 \\
\hline $\begin{array}{l}\text { External origin of raw } \\
\text { materials }\end{array}$ & $\mathrm{W}(\mathrm{R}) 1.5$ & 0.1702 & 0.0257 & 3 & 0.5106 & 0.3165 & 0.0479 \\
\hline $\begin{array}{l}\text { Participation of subcon- } \\
\text { tractors in organic pro- } \\
\text { duction }\end{array}$ & $\mathrm{W}(\mathrm{R}) 1.6$ & 0.2354 & 0.0356 & 1 & 0.2354 & 0.1459 & 0.0221 \\
\hline $\begin{array}{l}\text { Destination of products } \\
\text { (recipients) }\end{array}$ & $\mathrm{W}(\mathrm{R}) 1.7$ & 0.0742 & 0.0112 & 3 & 0.2226 & 0.1380 & 0.0209 \\
\hline $\begin{array}{l}\text { Parallel production of } \\
\text { conventional products }\end{array}$ & $\mathrm{W}(\mathrm{R}) 2$ & 0.3025 & 0.3025 & 1 & 0.3025 & 0.3025 & 0.3025 \\
\hline $\begin{array}{l}\text { The same production line } \\
\text { for organic and conven- } \\
\text { tional products }\end{array}$ & $\mathrm{W}(\mathrm{R}) 2.1$ & 0.6056 & 0.1832 & 5 & 3.0280 & 0.6575 & 0.1989 \\
\hline $\begin{array}{l}\text { Production of the same } \\
\text { goods in organic and } \\
\text { conventional versions }\end{array}$ & $\mathrm{W}(\mathrm{R}) 2.2$ & 0.3944 & 0.1193 & 4 & 1.5776 & 0.3425 & 0.1036 \\
\hline
\end{tabular}




\begin{tabular}{|c|c|c|c|c|c|c|c|}
\hline \begin{tabular}{|l|}
$\begin{array}{l}\text { Characteristics of enter- } \\
\text { prise }\end{array}$ \\
\end{tabular} & $\mathrm{W}(\mathrm{R}) 3$ & 0.0683 & 0.0683 & 1 & 0.0683 & 0.0683 & 0.0683 \\
\hline $\begin{array}{l}\text { Size of enterprise (num- } \\
\text { ber of employees) }\end{array}$ & $\mathrm{W}(\mathrm{R}) 3.1$ & 0.1318 & 0.0090 & 2 & 0.2636 & 0.0806 & 0.0055 \\
\hline Number of departments & $\mathrm{W}(\mathrm{R}) 3.2$ & 0.1382 & 0.0094 & 1 & 0.1382 & 0.0423 & 0.0029 \\
\hline $\begin{array}{l}\text { Staff characteristics } \\
\text { (knowledge, period of } \\
\text { employment, etc.) }\end{array}$ & $\mathrm{W}(\mathrm{R}) 3.3$ & 0.5348 & 0.0365 & 5 & 2.6740 & 0.8176 & 0.0558 \\
\hline $\begin{array}{l}\text { Localization of enterprise } \\
\text { (i.e. at own or others } \\
\text { premises) }\end{array}$ & $\mathrm{W}(\mathrm{R}) 3.4$ & 0.1948 & 0.0133 & 1 & 0.1948 & 0.0596 & 0.0041 \\
\hline $\begin{array}{l}\text { Implemented and certi- } \\
\text { fied systems of quality } \\
\text { management and food } \\
\text { safety assurance }\end{array}$ & $\mathrm{W}(\mathrm{R}) 4$ & 0.0555 & 0.0555 & 1 & 0.0555 & 0.0555 & 0.0555 \\
\hline \begin{tabular}{|l}
$\begin{array}{l}\text { Information about the } \\
\text { producer }\end{array}$ \\
\end{tabular} & $\mathrm{W}(\mathrm{R}) 5$ & 0.0966 & 0.0966 & 1 & 0.0966 & 0.0966 & 0.0966 \\
\hline $\begin{array}{l}\text { Opinions about the pro- } \\
\text { ducer (reputation) }\end{array}$ & $\mathrm{W}(\mathrm{R}) 5.1$ & 0.0518 & 0.0050 & 2 & 0.1036 & 0.0984 & 0.0095 \\
\hline $\begin{array}{l}\text { Informal impressions } \\
\text { about the previous coop- } \\
\text { eration }\end{array}$ & $\mathrm{W}(\mathrm{R}) 5.2$ & 0.0704 & 0.0068 & 1 & 0.0704 & 0.0669 & 0.0065 \\
\hline \begin{tabular}{|l} 
Complaints and ques- \\
tions received
\end{tabular} & $\mathrm{W}(\mathrm{R}) 5.3$ & 0.2194 & 0.0212 & 1 & 0.2194 & 0.2085 & 0.0201 \\
\hline Suspicion of fraud & $\mathrm{W}(\mathrm{R}) 5.4$ & 0.3244 & 0.0313 & 1 & 0.3244 & 0.3082 & 0.0298 \\
\hline $\begin{array}{l}\text { Failure to meet responsi- } \\
\text { bilities }\end{array}$ & $\mathrm{W}(\mathrm{R}) 5.5$ & 0.2454 & 0.0237 & 1 & 0.2454 & 0.2332 & 0.0225 \\
\hline $\begin{array}{l}\text { Participation in the next } \\
\text { stages of the food chain }\end{array}$ & $\mathrm{W}(\mathrm{R}) 5.6$ & 0.0892 & 0.0086 & 1 & 0.0892 & 0.0848 & 0.0082 \\
\hline $\begin{array}{l}\text { Experiences in certifica- } \\
\text { tion of organic production }\end{array}$ & $\mathrm{W}(\mathrm{R}) 6$ & 0.1164 & 0.1164 & 1 & 0.1164 & 0.1164 & 0.1164 \\
\hline $\begin{array}{l}\text { New producers (no } \\
\text { experience in certifica- } \\
\text { tion) }\end{array}$ & $\mathrm{W}(\mathrm{R}) 6.1$ & 0.1750 & 0.0204 & 5 & 0.8750 & 0.5147 & 0.0599 \\
\hline $\begin{array}{l}\text { The so far changes of } \\
\text { certification bodies }\end{array}$ & $\mathrm{W}(\mathrm{R}) 6.2$ & 0.3190 & 0.0371 & 1 & 0.3190 & 0.1876 & 0.0218 \\
\hline $\begin{array}{l}\text { Information about the } \\
\text { producer from Agric. and } \\
\text { Food Quality Insp. }\end{array}$ & $\mathrm{W}(\mathrm{R}) 6.3$ & 0.5060 & 0.0589 & 1 & 0.5060 & 0.2976 & 0.0346 \\
\hline $\begin{array}{l}\text { Results of the previous } \\
\text { controls (audits) }\end{array}$ & $\mathrm{W}(\mathrm{R}) 7$ & 0.2096 & 0.2096 & 1 & 0.2096 & 0.2096 & 0.2096 \\
\hline \begin{tabular}{|l|} 
Number of the previous \\
non-compliances
\end{tabular} & $\mathrm{W}(\mathrm{R}) 7.1$ & 0.5140 & 0.1077 & 2 & 1.0280 & 0.6791 & 0.1423 \\
\hline $\begin{array}{l}\text { Assessment of corrective } \\
\text { and preventive actions }\end{array}$ & $\mathrm{W}(\mathrm{R}) 7.2$ & 0.3832 & 0.0803 & 1 & 0.3832 & 0.2531 & 0.0530 \\
\hline $\begin{array}{l}\text { Assessment of documen- } \\
\text { tation of the quality } \\
\text { management systems }\end{array}$ & $\mathrm{W}(\mathrm{R}) 7.3$ & 0.1026 & 0.0215 & 1 & 0.1026 & 0.0678 & 0.0142 \\
\hline
\end{tabular}

Source: own research. 
The application of the AHP risk-benefit assessment ...

Table 11. Individual priorities for variants in the risk model.

\begin{tabular}{|c|c|c|c|c|c|c|}
\hline \multirow{2}{*}{ Criteria } & \multicolumn{3}{|c|}{ Local weights } & \multicolumn{3}{|c|}{ Global weights } \\
\hline & VAR. 1 & VAR. 2 & VAR. 3 & VAR. 1 & VAR. 2 & VAR. 3 \\
\hline \multicolumn{7}{|l|}{\begin{tabular}{|l|l|}
$\begin{array}{l}\text { Type of organic products } \\
\text { processes }\end{array}$ & \\
\end{tabular}} \\
\hline \multicolumn{7}{|l|}{ Complexity of products } \\
\hline $\begin{array}{l}\text { High quantity of various ingre- } \\
\text { dients used }\end{array}$ & 0.6048 & 0.1697 & 0.2255 & 0.0062 & 0.0017 & 0.0023 \\
\hline $\begin{array}{l}\text { The use of non-organic products } \\
\text { - annex IX }\end{array}$ & 0.5908 & 0.2429 & 0.1663 & 0.0062 & 0.0026 & 0.0017 \\
\hline $\begin{array}{l}\text { The use of yeast and yeast } \\
\text { products - annex VIII }\end{array}$ & 0.5857 & 0.2487 & 0.1655 & 0.0019 & 0.0008 & 0.0005 \\
\hline $\begin{array}{l}\text { Number of suppliers of raw } \\
\text { materials }\end{array}$ & 0.5851 & 0.2552 & 0.1596 & 0.0050 & 0.0022 & 0.0014 \\
\hline $\begin{array}{l}\text { Annual production / value of } \\
\text { products }\end{array}$ & 0.3333 & 0.3333 & 0.3333 & 0.0015 & 0.0015 & 0.0015 \\
\hline Number of production stages & 0.3333 & 0.3333 & 0.3333 & 0.0078 & 0.0078 & 0.0078 \\
\hline External origin of raw materials & 0.5793 & 0.2555 & 0.1652 & 0.0277 & 0.0122 & 0.0079 \\
\hline $\begin{array}{l}\text { Participation of subcontractors } \\
\text { in organic production }\end{array}$ & 0.5587 & 0.2702 & 0.1711 & 0.0123 & 0.0060 & 0.0038 \\
\hline $\begin{array}{l}\text { Destination of products (recipi- } \\
\text { ents) }\end{array}$ & 0.5209 & 0.2824 & 0.1966 & 0.0109 & 0.0059 & 0.0041 \\
\hline \multicolumn{7}{|l|}{$\begin{array}{l}\text { Parallel production of conven- } \\
\text { tional products }\end{array}$} \\
\hline $\begin{array}{l}\text { The same production line for } \\
\text { organic and conventional prod- } \\
\text { ucts }\end{array}$ & 0.6067 & 0.2422 & 0.1511 & 0.1207 & 0.0482 & 0.0301 \\
\hline $\begin{array}{l}\text { Production of the same goods in } \\
\text { organic and conventional ver- } \\
\text { sions }\end{array}$ & 0.5982 & 0.2509 & 0.1509 & 0.0620 & 0.0260 & 0.0156 \\
\hline \multicolumn{7}{|l|}{ Characteristics of enterprise } \\
\hline $\begin{array}{l}\text { Size of enterprise (number of } \\
\text { employees) }\end{array}$ & 0.5443 & 0.2595 & 0.1962 & 0.0030 & 0.0014 & 0.0011 \\
\hline Number of departments & 0.5152 & 0.2755 & 0.2093 & 0.0015 & 0.0008 & 0.0006 \\
\hline $\begin{array}{l}\text { Staff characteristics (knowledge, } \\
\text { period of employment, etc.) }\end{array}$ & 0.5248 & 0.2744 & 0.2008 & 0.0293 & 0.0153 & 0.0112 \\
\hline $\begin{array}{l}\text { Localization of enterprise (i.e. at } \\
\text { own or others premises) }\end{array}$ & 0.5708 & 0.2641 & 0.1651 & 0.0023 & 0.0011 & 0.0007 \\
\hline \begin{tabular}{|l} 
Implemented and certified \\
systems of quality management \\
and food safety assurance
\end{tabular} & 0.3659 & 0.4091 & 0.2250 & 0.0203 & 0.0227 & 0.0125 \\
\hline \multicolumn{7}{|l|}{ Information about the producer } \\
\hline $\begin{array}{l}\text { Opinions about the producer } \\
\text { (reputation) }\end{array}$ & 0.4913 & 0.2455 & 0.2632 & 0.0047 & 0.0023 & 0.0025 \\
\hline $\begin{array}{l}\text { Informal impressions about the } \\
\text { previous cooperation }\end{array}$ & 0.4914 & 0.2427 & 0.2659 & 0.0032 & 0.0016 & 0.0017 \\
\hline $\begin{array}{l}\begin{array}{l}\text { Complaints } \\
\text { received }\end{array} \\
\end{array}$ & 0.5241 & 0.2283 & 0.2475 & 0.0105 & 0.0046 & 0.0050 \\
\hline Suspicion of fraud & 0.5295 & 0.2260 & 0.2446 & 0.0158 & 0.0067 & 0.0073 \\
\hline Failure to meet responsibilities & 0.5631 & 0.2027 & 0.2342 & 0.0127 & 0.0046 & 0.0053 \\
\hline
\end{tabular}




\begin{tabular}{|c|c|c|c|c|c|c|}
\hline $\begin{array}{l}\text { Participation in the next stages } \\
\text { of the food chain }\end{array}$ & 0.5699 & 0.2026 & 0.2275 & 0.0047 & 0.0017 & 0.0019 \\
\hline \multicolumn{7}{|l|}{$\begin{array}{l}\text { Experiences in certification of } \\
\text { organic production }\end{array}$} \\
\hline $\begin{array}{l}\text { New producers (no experience } \\
\text { in certification) }\end{array}$ & 0.5551 & 0.2712 & 0.1737 & 0.0333 & 0.0162 & 0.0104 \\
\hline $\begin{array}{l}\text { The so far changes of certifica- } \\
\text { tion bodies }\end{array}$ & 0.5868 & 0.2481 & 0.1651 & 0.0128 & 0.0054 & 0.0036 \\
\hline $\begin{array}{l}\text { Information about the producer } \\
\text { from Agric. and Food Quality } \\
\text { Insp. }\end{array}$ & 0.5992 & 0.2413 & 0.1595 & 0.0207 & 0.0083 & 0.0055 \\
\hline \multicolumn{7}{|l|}{$\begin{array}{l}\text { Results of the previous controls } \\
\text { (audits) }\end{array}$} \\
\hline $\begin{array}{l}\text { Number of the previous non- } \\
\text { compliances }\end{array}$ & 0.6025 & 0.2435 & 0.1540 & 0.0857 & 0.0347 & 0.0219 \\
\hline $\begin{array}{l}\text { Assessment of corrective and } \\
\text { preventive actions }\end{array}$ & 0.5693 & 0.2018 & 0.2289 & 0.0302 & 0.0107 & 0.0121 \\
\hline \multirow[t]{3}{*}{\begin{tabular}{|l|}
$\begin{array}{l}\text { Assessment of documentation of } \\
\text { the quality management systems }\end{array}$ \\
\end{tabular}} & 0.5631 & 0.2065 & 0.2304 & 0.0080 & 0.0029 & 0.0033 \\
\hline & & & & 0.5609 & 0.2559 & 0.1833 \\
\hline & & & & $\mathrm{W}(\mathrm{R}) \mathrm{V} 1$ & $\mathrm{~W}(\mathrm{R}) \mathrm{V} 2$ & W(R)V3 \\
\hline
\end{tabular}

Source: own research.

The final $\mathrm{B} / \mathrm{R}$ ratio (Table 12) is therefore dependent on the results of stage 1 (general importance of risk and benefit factors and degree of their fulfillment by each variant of surveillance) and stage 2 (relevance of the risk factors to individual client). It shows that for this particular company, $\mathrm{B} / \mathrm{R}$ ratio is the highest for variant $3(\mathrm{~W}(\mathrm{~B} / \mathrm{R}) \mathrm{V} 3=0,9640)$, as it was in general model, and indicates the optimal solution.

Table 12. $\mathrm{B} / \mathrm{R}$ ratio for individual model.

\begin{tabular}{|c|c|c|c|}
\hline Risk/Benefit & $\begin{array}{c}\text { Standard control } \\
\text { plan (SCP) }\end{array}$ & $\begin{array}{c}\text { SCP + testing of samples from pro- } \\
\text { duction or SCP + additional audit }\end{array}$ & $\begin{array}{c}\text { SCP+ testing of samples from produc- } \\
\text { tion + additional audit }\end{array}$ \\
\hline B & 0.3601 & 0.2217 & 0.4183 \\
\hline R & 0.5609 & 0.2559 & 0.1833 \\
\hline B/R & 0.6420 & 0.8664 & 2.2821 \\
\hline
\end{tabular}

Source: own research.

\section{CONCLUSION}

In the market of organic food, consumer trust is an important issue, since consumers are not able to verify whether a product is an organic product, not even after consumption $^{41}$. Consumers are forced to trust that the operating system to control is effective. Only few studies can be found questioning the trustworthiness of third-party certification and addressing the problems of auditor independence and objectiveness ${ }^{42}$. Despite the assumption that certification bodies act in good faith, the use of appropriate risk assessment tools is crucial to increase the effectiveness of inspections and consequently, raise the consumer

\footnotetext{
${ }^{41}$ Janssen M., Hamm U., Product labelling in the market for organic food: Consumer preferences and willingness-to-pay for different organic certification logos, "Food Quality and Preference" 25 (2012), pp. 9-22.

${ }^{42}$ Albersmeier F., Schulze H., Jahn G., Spiller A., The reliability..., op. cit., pp. 927-935.
} 
trust. Although the regulations oblige the certification bodies to conduct risk assessment ${ }^{43}$, there are no specific procedures provided on this issue.

The objective of the present study was to demonstrate a new approach to risk and benefit assessment of organic producers in the process of their certification. This approach is based on one of the decision support methods, the Analytic Hierarchy Process. The decision to be taken in this process is which variant of surveillance (control scenario) is optimal for a particular organic producer applying for the certification. Two hierarchical models, risk and benefit, have been developed by experts from one of the major certification bodies in Poland, experienced in certification of organic products. These models have been analyzed in two stages: (1) evaluation of criteria, subcriteria and variants in risk and benefit models, resulting in general (base) priorities; (2) indicating the relevance of the risk factors for a selected producer and deriving individual B/R ratio. General results obtained in stage 1 allow producing a universal, base model that can be applied for risk assessment of any organic producer in certification bodies. In turn, stage 2 demonstrates a simple way of individualization of the general model to the specific producer. The AHP method was selected as having several advantages, including simple and user-friendly software for deriving priorities and possibility to run risk-benefit assessment. Models and templates developed during the study respond to a real need of certification bodies. However, several conditions must be fulfilled before implementation of the proposed models and templates in practice. First, although the risk-benefit models have been developed based on the pertinent documents and discussions with the relevant experts, they should be adjusted to individual needs of a certification body, for example, some organizations adopt more severe criteria in certifying their clients, while some others are prone to certify without an in-depth verification.

The certification body described in this paper belongs to organizations that certify their clients very carefully, following a long and careful risk assessment. For the same reason, the models should be analyze dinternally by the employees of the certification body, and the analysis should be repeated once in a while to record and analyze changes that happen over time. In addition, due to complexity of the proposed models, in most organizations, the application of risk-benefit assessment requires refinement of the quality management system.

Adnotacja: Badania zaprezentowane w artykule zostały sfinansowane ze środków Narodowego Centrum Nauki przyznanych na podstawie decyzji nr DEC-2011/01/D/HS4/04006.

\section{LITERATURA}

[1] Albersmeier F., Schulze H., Jahn G., Spiller A., The reliability of third party certification in the food chain: from checklists to risk-oriented auditing, "Food Control" 20(10), (2009), pp. 927-935.

[2] Alphonce Ch., Application of the Analytic Hierarchy Process in Agriculture in Developing Countries, "Agricultural Systems" 53 (1997), pp. 97-112.

[3] Apostolou B., Hassel J.M., An empirical examination of the sensitivity of the analytic hierar-

\footnotetext{
${ }^{43}$ EC, Commission Regulation (EC) No 889/2008 of 5 September 2008 laying down detailed rules for the implementation of Council Regulation (EC) No 834/2007 on organic production and labelling of organic products with regard to organic production, labelling and control (http://eur-lex.europa.eu); EC, Commission Implementing Regulation (EU) No 392/2013 of 29 April 2013 amending Regulation (EC) No 889/2008 as regards the control system for organic production (http://eur-lex.europa.eu).
} 
chy process to departures from recommended consistency ratios, "Mathematical and Computer Modeling”, 4/5 (1993), pp. 163-170.

[4] Beuchelt T.D., Zeller M., Profits and poverty: Certification's troubleed link for Nicaragua's organic and fairtrade coffee producers, "Ecological Economics" 70 (2011), pp. 1316-1324.

[5] Chavez M.D., Berentsen PP.B.M., Oude Lansink A.G.J.M., Assessment of criteria and farming activities for tobacco diversification using the Analytical Hierarchical Process (AHP) technique, "Agricultural Systems" 111 (2012), pp. 53-62.

[6] Demiryurek K., Analysis of information systems and communication networks for organic and conventional hazelnut producers in the Samsun province of Turkey, "Agricultural Systems" 103 (2010), pp. 444-452.

[7] EC, Council Regulation (EC) No 834/2007 of 28 June 2007 on organic production and labelling of organic products and repealing Regulation (EEC) No 2092/91.

[8] EC, Commission Regulation (EC) No 889/2008 of 5 September 2008 laying down detailed rules for the implementation of Council Regulation (EC) No 834/2007 on organic production and labelling of organic products with regard to organic production, labelling and control (http://eur-lex.europa.eu).

[9] EC, 2009, Guidelines on official controls in the organic sector, 10 December, Draft 1,. Directorate-general for agriculture and rural development (http://eur-lex.europa.eu).

[10] EC, Commission Implementing Regulation (EU) No 392/2013 of 29 April 2013 amending Regulation (EC) No 889/2008 as regards the control system for organic production (http://eurlex.europa.eu).

[11] Ec.europa.eu, http://ec.europa.eu/agriculture/organic/consumer-confidence/inspectioncertification_en

[12] Forman E., Peniwati K., Aggregating individual judgments and priorities with the Analytic Hierarchy Process, "European Journal of Operational Research" 108 (1998), pp. 165-169.

[13] IJHAR-S, http://www.ijhar-s.gov.pl/organic-farming.html

[14] ISO, ISO/IEC 17000:2004, Conformity assessment. Vocabulary and general principles (https://law.resource.org).

[15] ISO, ISO/IEC Guide 67:2004 Conformity assessment. Fundamentals of product certification (https://law.resource.org).

[16] Jahn G., Schramm M., Spiller A., The Reliability of Certification: Quality Labels as a Consumer Policy Tool, "Journal of Consumer Policy" 28 (2005), pp. 53-73.

[17] Janssen M., Hamm U., Product labelling in the market for organic food: Consumer preferences and willingness-to-pay for different organic certification logos, "Food Quality and Preference" 25 (2012), pp. 9-22.

[18] Karami E., Appropriateness of farmers' adoption of irrigation methods: The application of the AHP model, "Agricultural Systems" 87 (2006), pp. 101-119.

[19] Kleemann L., Abdulai A., Organic certification, agro-ecological practices and return on investment: Evidence from pineapple producers in Ghana, "Ecological Economics" 93 (2013), pp. 330-341.

[20] Konefal J., Hatanaka M., Enacting third-party certification: A case study of science and politics in organic shrimp certification, "Journal of Rural Studies" 27 (2011), pp. 125-133.

[21] Lobley M., Butler A., Reed M., The contribution of organic farming to rural development: An exploration of the socio-economic linkages of organic and non-organic farms in England, "Land Use Policy" 26(3), (2009), pp. 723-735.

[22] Prusak A., Stefanów P., Badania nad wtaściwościami metody AHP (Operational features of the AHP method, in Polish), "Folia Oeconomica Cracoviensia" LII (2011), pp. 87-104.

[23] Prusak A., Stefanów P., AHP - analityczny proces hierarchiczny. Budowa i analiza modeli decyzyjnych krok po kroku, wyd. 1, C.H. Beck, Warszawa 2014.

[24] Saaty R., Decision making in complex environments. The Analytic Network Process (ANP) for Dependence and Feedback including a Tutorial for the SuperDecisions Software and Portions of the Encyclicon of Applications, 2002. 
[25] Saaty T.L., The Analytic Hierarchy Process: Planning, Priority Setting, Resource Allocation, McGraw-Hill, 2nd edition, New York, 1980.

[26] Saaty T.L., Decision Making with Dependence and Feedback. The Analytic Network Process, second ed. RWS Publications, Pittsburgh, 2001.

[27] Saaty T.L., Fundamentals of Decision Making and Priority Theory with the Analytic Hierarchy Process, Vol. VI of The AHP Series, Pittsburgh, 2006.

[28] Saaty T.L., Relative Measurement and Its Generalization in Decision Making. Why Pairwise Comparisons are Central in Mathematics for the Measurement of Intangible Factors, The Analytic Hierarchy/Network Process, "Rev. R. Acad. Cien. Serie A. Mat.", 102(2), (2008), pp. 253-318.

[29] Saaty T.L., Decision Making for Leaders. The Analytic Hierarchy Process for Decisions in a Complex World, RWS Publications, Pittsburgh, 2008.

[30] Saaty T.L., Forman E.H., The Hierarchon. A Dictionary of Hierarchies (Analytic Hierarchy Process), RWS Publications, Pittsburgh, 1992.

[31] Uematsu H., Mishra A.K., Organic farmers or conventional farmers: Where's the money?, "Ecological Economics" 78 (2012), pp. 55-62.

[32] Zorn A., Lippert Ch., Dabbert S., Supervising a system of approved private control bodies for certification: The case of organic farming in Germany, "Food Control" 25 (2012), pp. 525-532.

[33] Zorn A., Lippert, Ch. Dabbert, S., An analysis of the risks of non-compliance with the European organic standard: A categorical analysis of farm data from a German control body, "Food Control" 30 (2013), pp. 692-699.

\section{ZASTOSOWANIE ANALIZY RISK-BENEFIT AHP W CERTYFIKACJI RONICTWA EKOLOGICZNEGO}

Celem badań jest opracowanie modeli oceny ryzyka i korzyści w oparciu o metodę analitycznego procesu hierarchicznego (AHP) i zastosowanie ich w procesie certyfikacji produktów ekologicznych. Norma ISO 65 /EN 45011 oraz Rozporządzenie (EC) nr 834/2007 zobowiązuje jednostki certyfikujące do przeprowadzenia oceny ryzyka w procesie certyfikacji. Jednak nie opracowano jak dotąd w tym zakresie jednolitej metodologii. Metoda AHP pozwala na dekompozycję złożonego problemu decyzyjnego i przedstawienie go w postaci struktury hierarchicznej, złożonej z celu, kryteriów oraz wariantów decyzyjnych. W omawianym przypadku zostały zbudowane dwa odrębne modele: korzyści i ryzyka, w oparciu o dostępne źródła literaturowe oraz na bazie konsultacji z kluczowymi ekspertami pracującymi w jednej z dziewięciu zewnętrznych jednostek certyfikujących w Polsce, specjalizujących się w certyfikacji produktów ekologicznych. Obydwa modele mają te same warianty decyzyjne uwzględniane w procesie certyfikacji. Wyniki pokazały, że największe ryzyko dla produkcji ekologicznej to Produkcja równoległa wyrobów konwencjonalnych. W modelu korzyści, najważniejsze okazały się zaufanie do wyrobów certyfikowanych oraz minimalizacja kosztów niewłaściwych decyzji. Modele AHP okazały się bardzo przydatne w ocenie korzyści-ryzyka producentów wyrobów ekologicznych. Pokazane zostało nowe podejście do oceny ryzyka. Należy jednak pamiętać, że wdrożenie tego modelu w praktyce wymaga spełnienia pewnych warunków, jak np. indywidualne potrzeby danej jednostki certyfikującej i dążenie do doskonalenia systemu zarządzania jakością.

Słowa kluczowe: AHP, certyfikacji, analizy ryzyka i korzyści, oceny ryzyka, rolnictwo ekologiczne, certyfikacji osób trzecich.

DOI: 10.7862/rz.2015.mmr.60

Tekst złożono w redakcji: październik 2015

Przyjęto do druku: grudzień 2015 